ガスクロマトグラフィーによる天然精油の検討（第 8 報 ${ }^{1)}$ ) 菜本の精油についで2)

\author{
斎木保久, 岡本 (旧姓鈴木) 雅子, 上野 明, 内田三夫, 福島清吾 \\ 静岡薬科大学 ${ }^{3}$
}

\title{
Gas Chromatographical Studies on Natural Volatile Oils. VIII.1) On the Essential Oils of Chinese Medicins "Gaoben" 2)
}

\author{
Yasuhisa Saiki, Masako Okamoto (née Suzuki), Akira Ueno, Mitsuo Uchida \\ and Seigo Fukushima \\ Shizuoka College of Pharmacy)
}

(Received October 3, 1969)

\begin{abstract}
Gas chromatographic examinations were made on the essential oils of Chinese and Japanese Gaobens (Kôhon) and related plants, namely, Nothosmymium japonicum and Osmorhiza aristata.

The essential oil of Chinese Gaoben, whose original plant is Ligusticum sinense, contains mainly 3-butylphthatide, cnidilide, and an un-didentified compound $\mathrm{X}$, and its chemical nature is similar to that of Japanese Chuanxiong (Senkyu, Cnidii Rhizoma).

One of Japanese Gaobens now on the market consists mainly of osmorhizole $(2,4$ dimethoxy-1-allylbenzene), isoosmorhizole (nothosmyrnole, 2,4-dimethoxy-1-propenylbenzene), and anethole, and the chemical constituents are the same as those of the oil of Osmorhiza aristate.

The oil of Nothosmyrnium japonicum contains mainly dillapiole, nothoapiole, and an un-identified compound, and the structure of nothoapiole is assumed to be $2,3,6-$ trimethoxy-4,5-methylendioxy-1-allylbenzene.

During synthesis of osmorhizole (Chart 1), the Claisen rearrangement was found to occur at two ortho positions.
\end{abstract}

漢薬の藻本 (Gaoben) 怙くから知られたセり科 (Umebelliferae) の植物を基源とする生薬で，鎮痛，鎮痓など

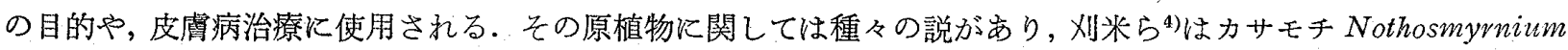

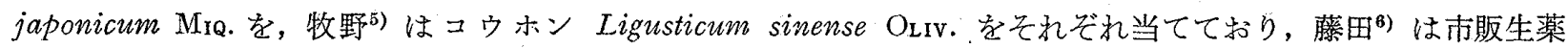
の内部形態の詳細な研究から中国および朝鮮産のものにコウホンを，日本産のるのにカサモチを当てている．立 た近年の中国文献7,8)によれば，中国の市場品には 2 種の生薬があり，遼拲本には，Ligusticum jeholencse $\mathrm{N}_{\mathrm{AK} A \mathrm{I}}$ et K KTAG. を，西芦藥本にはコウホンを各れぞれ当てている.

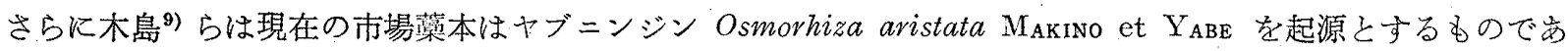
ると内部形態から述べている.

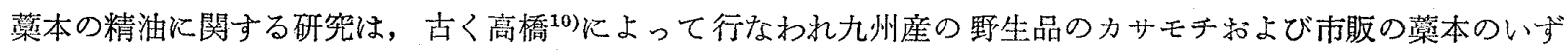
れる成分は同じで，いずれる nothosmyrnole (2 4-dimethyoxy-1-propenylbenzene) おょび゙ 2,4-dimethoxy-1allylbenzene を含むと述べている。

1）第 7 報：斎木保久, 佐野智子, 福島清吾, 薬誌, 70, 103 (1970).

2) 本研究の一部注日本薬学会第87年会, 1967 年 4 月, に発表してある.

3) Location: Oshika Shizuoka.

4）刏米達夫，木村雄四郎，“和漠薬用植物，”広川書店，1954, p. 143.

5）牧野富太郎“頭註国訳本草綱目,”第 4 冊, 春陽堂 1930, p. 42.

6) 藤田路一, 植研, 20, 301, 312 (1944).

7) 中国医学科学院䒺物研究所等編 “中葯志, ' I, 人民衛生社, 1961， p. 515.

8) 南京薬学院薬材学教研組集体編, “葯材学,” 人民衛生社, 1961, p. 610.

9）木島正夫, 秦 清之, 平岡 昇, 生薬, 21, 22 (1967).

10) 高橋武勇, 日化, 49, 534 (1928); 50, 356, 719 (1929). 
また近年，木島ら ${ }^{11}$ はヤブニンジン执よび市場の和蕒本が，いずれも高橋がカサモチより証明したというこれ らの成分を含有し，カサモチの精油には不詳の別成分の存在を報告し，これと注同様の結果を著者らすすでに 発表した.2)

本報は，さきに発表した内容を発展させたものであり，現在わが国に出廹っている日本産と称する和菱本，中 国産と称する唐賟本および従来からこれらの原植物とみられたカサモチ特よびヤブニンジンの地下部をそれぞれ 材料に用い，それぞれ精油をとり，ガスクロマトグラフィー（以下 GC と略記）を用いながら，薄層クロマトグ ラフィ一（以下，TLCと略記）で分離し成分同定を行ない，ガズロマトグラムに現れる主なピークの成分を明 かにしたものである.

それぞれの精油のガスクロマトグラムを Fig.1 および 2 に示し，それぞれピークの偭積此より算出せる成分 租成を Table I に示吉.

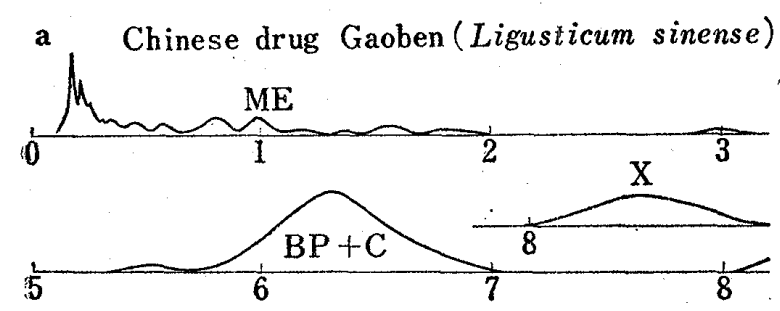

b Japanese drug Gaoben (Osmorhiza aristata)
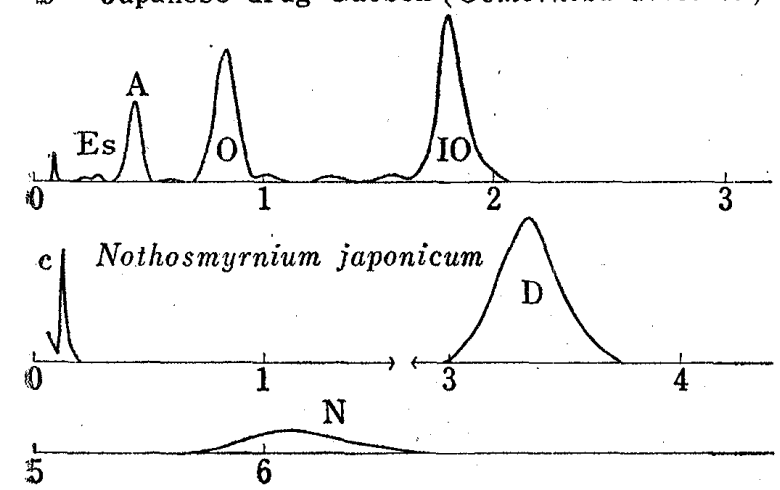

d Osmorhiza aristata

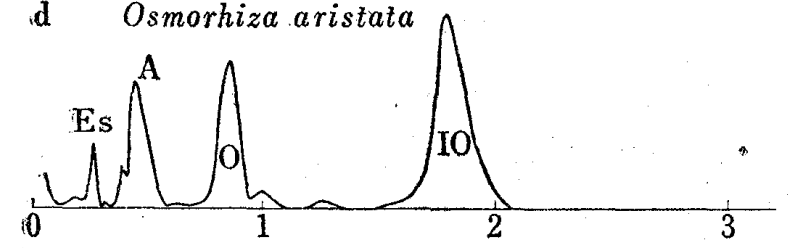

Fig. 1. The Gas-Chromatograms of the Essential Oils on each Drug and Plant

condition :

column: $20 \%$ DEGS on C-22, $0.4 \mathrm{~cm} \times 75 \mathrm{~cm} \quad$ C.B. $150^{\circ}$, D.B.: $170^{\circ}$ S.C.: $220^{\circ}$ carrier gas: $\mathrm{N}_{2} 55 \mathrm{ml} / \mathrm{min}$ ditecter: H.F. I.D. $\mathrm{H}_{2}: 87 \mathrm{ml} / \mathrm{min}$

次にこれら精油の特徽と成分の同定にいたる経緯につ いて述へよう。

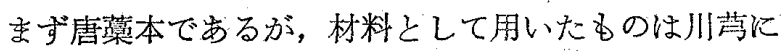
類似したやや小形の根菱を主とした生薬で，外面は赤褔 色で川岂より乾かく香気子似ているが幾分悪臭を带び， 西芺㩰本の外的特徵と一致し，内部形態も藤田の報告6) と矛盾しないので原植物はコウホン Ligusticum sinense OLIV. と判定したものである.
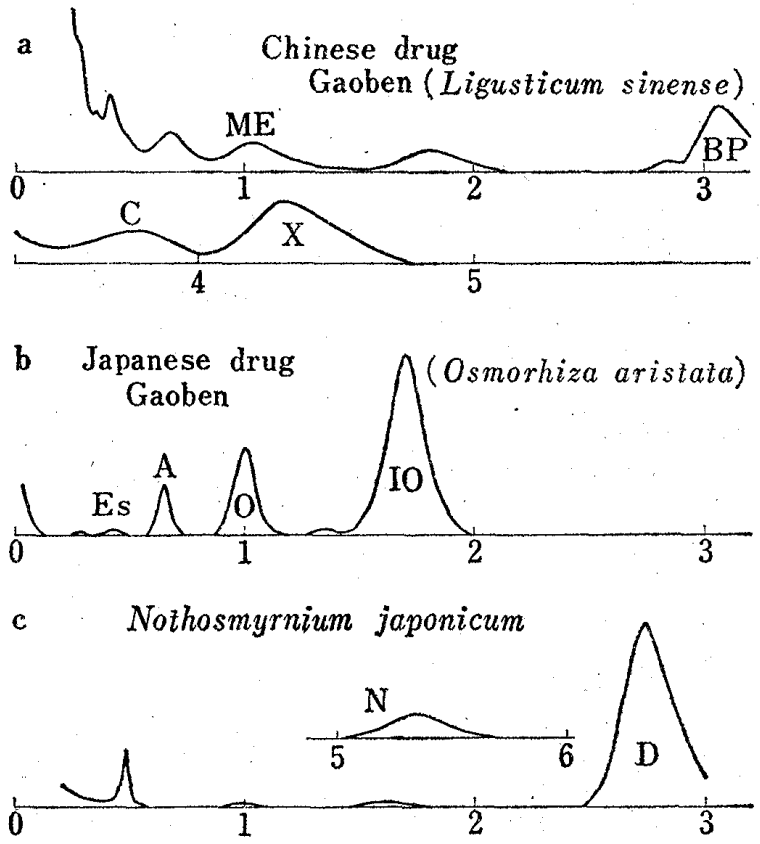

d Osmorhiza aristata

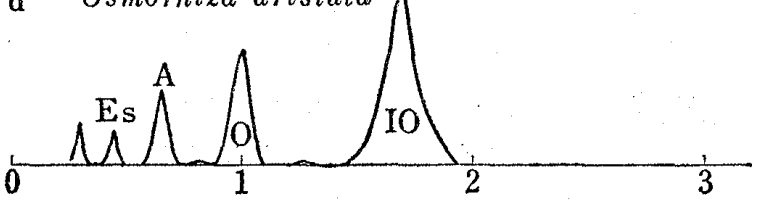

Fig. 2. The Gas-Chromatograms of the Essential Oils on each Drugs and Plants condition:

column: $10 \% \mathrm{SE}-30$ on $\mathrm{C}-22,0.4 \mathrm{~cm} \times 75 \mathrm{~cm} \quad \mathrm{CB} .: 150^{\circ}$,

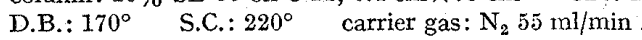
ditecter: H.F.I.D. $\quad \mathrm{H}_{2}: 87 \mathrm{ml} / \mathrm{min}$

The standard material of retention time is methyleugenol, and its retention times are $14.0 \mathrm{~min}$ and $4.7 \mathrm{~min}$ in the cases of Fig. 1 and 2 , respectively.

The abbreviations are following.

$\mathrm{D}$ : dillapiole, A: trans-anethole, O: osmorhizole (1-allyl, 2, 4-dimethoxybenzene), IO: iso-osmorhizole (=nothosmyrnole, trans-1-propenyl, 2,4-dimethobenzene), BP: butylphthalide, $\mathrm{C}$ : cnidilide, Es: estragole, ME: methyleugenol,

$\mathrm{X}$ : unidentified, $\mathrm{N}$ : nothoapiole

11) 木鳥正夫, 秦, 清之, 池城安正, 薬誌, 87, 1138 (1967). 
TABLE I. Chemical Constituents of the Essential Oils and Their Compositions

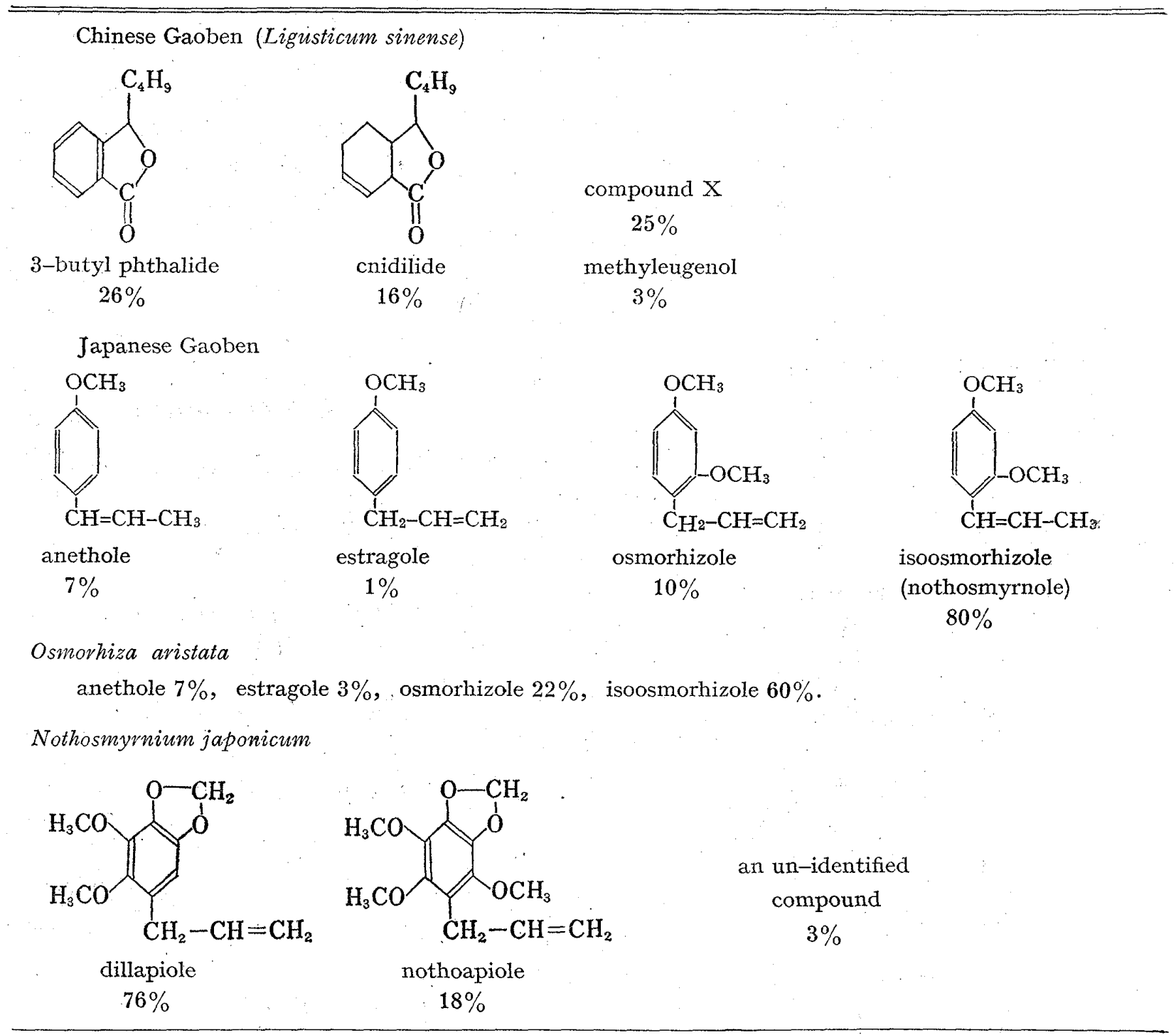

本種生薬の精油は保持時間の大きい3 個のピークが特徵で,・この内 2 個は 3-butylphthalide ${ }^{12)}$ および cnidili$\mathrm{de}^{13}$ )であることを分離したのら赤外線 (IR) スペクトルの比較により確認した. 残りのピーク (Fig. 1 拈よび 2 の

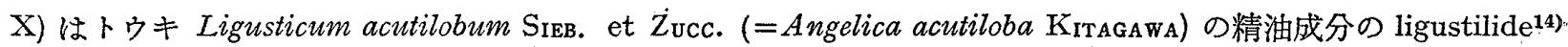
の保持時間とよく一致するので，このピークを与える物質を分離し，トウキより分離した ligustilide と比較した ところ，TLCにてRf 值，呈色反応，䖝光が異って和り，また香気もちがい別の物質とみられる. この物質の構 造その他については目下笑明中で次の機会に結果を述べよと思 5。他の少量のみ含まれる主として保持時間の 小さい物質は， methyleugenol と保持時間から推定されるすののほか確認するにいたらなかったので以上疑問点 は今後追求の予定である.

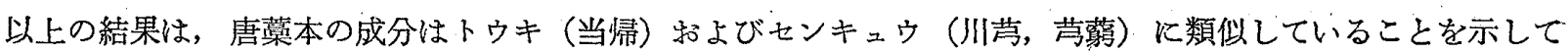
牤り，ことに川芦とは外形も類似しているだけに成分の親近性は植物の親近性を示するのと考えられる.このこ

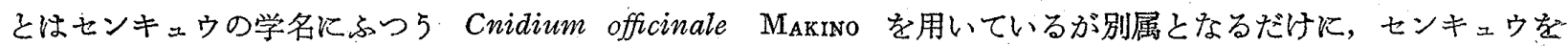
Ligusticum officinale KITAGAWA とする見解 ${ }^{15)}$ 支持する.

12) H. Mitsuhashi, U. Nagai, T. Muramatsu, Chem. Pharm. Bull. (Tokyo), 9, 115 (1961).

13) H. Bohrman, E. Stahl, H. Mitsuhashi, Chem. Pharm. Bull. (Tokyo), 15, 1606 (1967).

14) H. Mitsuhashi, U. Nagai, T. Muramatsu, H. Tashiro, Chem. Pharm. Bull. (Tokyo), 8, 243 (1960).

15）杉本順一，“日本草本植物検索誌，”双子葉編，六月社，1964，p. 394: 
またわが国の载培センキュウと内外部ともに形態のきわめて酷似している中国産センキュウにLigusticum

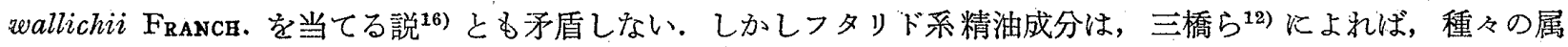
にまたがって分布して和り，余り類縁関係の著しくない植物間に共通成分として含まれるようにす見受汁られる ので，含有植物とその親近性についてはさらに多くのセリ科植物について調查し結論を出したいと思う。

次いで，現在の市場品の和菜本执よび野生のヤブニンジンの地下部の精油について述べる。これらの精油は Fig. 1 牤よび 2, Table I に示されるように主ピークは完全に一致し，同一材料とみられすなおち現在の市場和蒸 本はヤブニンジンを基源することを示し，木島 ${ }^{9,11)}$ らの結果とよく一致する．3 個の主ピークを示す物質が nothosmyrnole (2,4-dimethoxy-1-propenylbenzene), 2,4-dimethoxy-1-allylbenzene 拉よび anethole (4-methoxy1-propenyl benzene) であることは標品との比較により決定した。他のピークは，いずれる少量のみ含まれるた め，保持時間により methylchavicol (=estragol, $p$-methxyallylbenzene) を推定した他は同定できなかった。

以上の結果は，唐䍒本を本草書記載の正条の生薬とすれば，精油成分が有効成分であるか不明にせよ，ヤブ二 ンジンを起源とする和涪本は偽品にすぎないのとみられる.

次ぎにカサモチの精油について述べる，カサモチの精油の成分については，木島ら师はヤブニンジンに含まれ

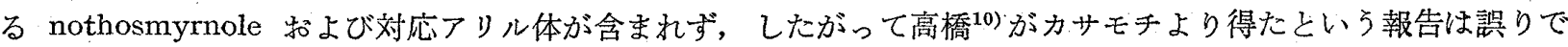
あることを指摘しているが，その精油成分については別の成分といらのみで同定していない。この精油のガスク ロマトグラムは，Fig. 1 拉よび 2 に示されるように，3 個のピークにて代表され，他の成分にさわめて少ない. もっとも含量の多い成分が dillapiole (2,3-dimethoxy-4,5-methylendioxy-1-allylbenzene) であることは TLC にて分離した後，同定した。

保持時間のもっとも大きい成分は，TLCにては dillapiole よりわずか小さいRf 值を示し互に分離は困難であ るが，紫外線下で dillapiole が青色螢光を与えるに対しこの物質は暗色となるので䖝光を目標に TLC る繰返し て純粋とみられる油状物質少量を得た。この物質の IR スペクトルは dillapiole のスペクトルに酷似しているが 面外変角振動の領域にベンゼン核水素の吸収を認めないので，ベンゼン核の水素はすべて置換されたものと考完 られる。また質量 (MS) スペクトル (Fig. 4) は親イオン m/e 252 示し分子式は $\mathrm{C}_{13} \mathrm{H}_{16} \mathrm{O}_{5}$ に相当する. 核磁気 共鳴 (NMR) スペクトル (Fig. 3) より, $\tau 6.73$ の $2 \mathrm{H}$ に相当する細かく分裂する doublet $(J=6.0$ cps) は $\mathrm{C}_{6} \mathrm{H}_{5}-\mathrm{CH}_{2}-\mathrm{CH}=\mathrm{CH}_{2}$ に, $\tau 5.2$ および 4.9 の $1 \mathrm{H}$ 相当の分裂する 2 個の singlet は-CH$\mathrm{CH}_{2}$ に, $\tau 3.8-4.5$ の $1 \mathrm{H}$ に相当する multiplet は $\mathrm{C}_{6} \mathrm{H}_{5}-\mathrm{CH}_{2}-\mathrm{CH}=\mathrm{CH}_{2}$ に, さらに $\tau 6.27$ の $3 \mathrm{H}$ 柏当の singlet 3 位の-OCH に， $\tau 6.12 の 6 \mathrm{H}$ 相当の singletを 2 执よび 6 位の-OCH 3 に， $\tau$ $4.18 の 2 \mathrm{H}$ 相当の singlet 4.5 位の-O-CH 一Oーに，それぞれ帰属させれば，この物質は $2,3,6$ trimethoxy-4,5-methylendioxy-1-allylbenzene であると考えられる: MS スペクトル (Fig. 4) もこの 構造を支持し, 親イオン $m / e 252$ がもっとも大きく， m/e $92,90,78,77,68,64,52$ などの各ピークが十分に 大きいことからベンゼン核の存在字示し，しかも炭素 鎖をもつことが判る：また $m / e 225$ は親イオンより $\mathrm{C}_{2} \mathrm{H}_{3}$ が取れたるの, すなおら allyl 基の二重結合の 隣で切れたもの，m/e 222 は $\mathrm{CH}_{2} \mathrm{O}$-の取れたもの， m/e 206 は $\mathrm{CH}_{2} \mathrm{O}_{2}$ の取れたものでメチレンジオキシ 基の存在を示し, m/e 190 は 2 個の $\mathrm{CH}_{2} \mathrm{O}$-の取れた もの, m/e 179 は $m / e 225$ より 2 個のメチル基の取

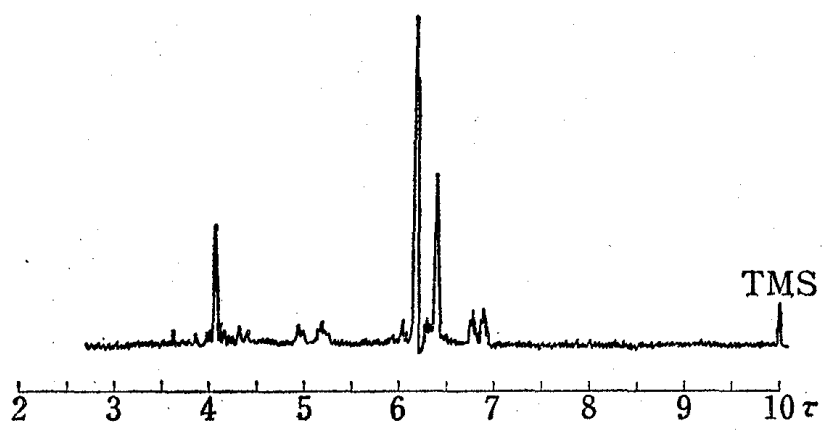

Fig. 3. The Nuclear Magnetic Resonance Spectrum of Nothoapiole in $\mathrm{CCl}_{4}$

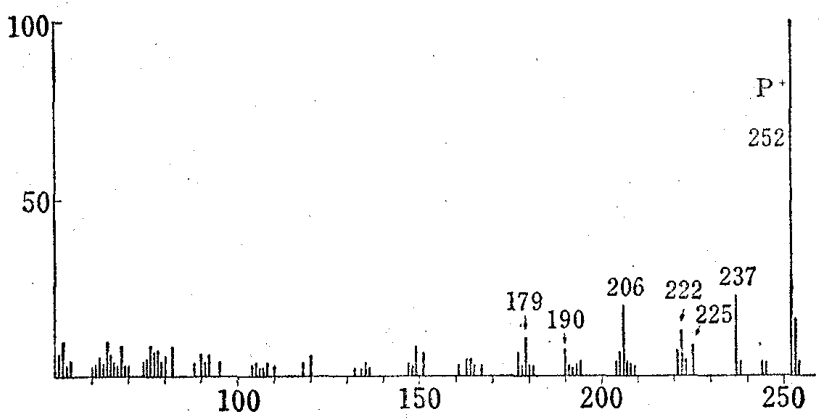

Fig. 4. The Mass Spectrum of Nothoapiole

16)，中国医学科学院蔽物研究所等編，“中䓎志,” I, 1961， p. 67 . 
れたものと，それぞれ考兇れ゙矛盾なく説明される。な和，この物質の棈造確認には合成品との比較が望ましい ので今後合成して比較検討の予定である：この物質はフェニルプロペソ系精油成分としてはるっとも酸素数の多 い多価フェノールェーテルであり，沸点も高く香気もなく香料としての洒值はないが，天然精油成分として単離 されたのは本実験が始めてであり，かつ文献未知の物質と考劣られるので新たに nothoapiole と命名する.

保持時間の小さい物質は，3 個の成分の内もっとも収量も悪く純粋に単離できなかったので後に精查の予定で ある.

以上の結果を要的し，各精油成分の内，構造の判明てているものの構造式を示せば Table Iのようである.

この結果は，これらの精油成分には著しい差のあることを示して抢り，原植物は互に類緑の遠いことを示して いる.すなわち，3-butylphthalide, cnidilide などのセンキュウトウキ成分に類似の化合物と, anethole, nothosmyrnole, dillapioleなどフェニルプロペン類では構造式をみただけで先験的に生合成経路が異質であると考 えられるが, dillapiole と 2,4-dimethoxy-1-allylbenzene p nothosmyrnole との間にも, 同じフェニルプロペン 類であるが，著しい成分分類において差を認め得る。これは 2,4-dimethoxy-1-allylbenzene 拈よび nothosmyrnole のいずれも， $\mathrm{C}_{3}$ の側鎖に対し 2,4 位にレゾルシン型の置換基をもちフェニルプロペン系精油成分では異例 とみられるからである。これに反し dillapiole などでは safrole (3,4-methylendioxy-1-allylbenzene) 一 myristicin (3,4-methylendioxy-5-methoxy-1-allylbenzene)—dillapiole および apiole (2,3-dimethoxy-4,5-met-<smiles>COc1cccc(O)c1</smiles>

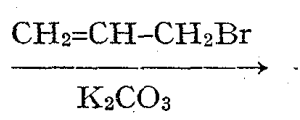

(a)<smiles>C=CCC(C(=C)O)=C(C)OC</smiles>

II<smiles></smiles>

V

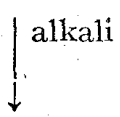

$\mathrm{OCH}_{3}$<smiles>CC=Cc1c(OC)cccc1OC</smiles>

VI

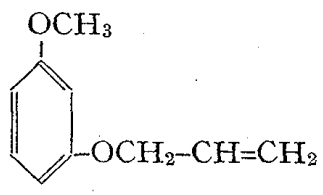

I
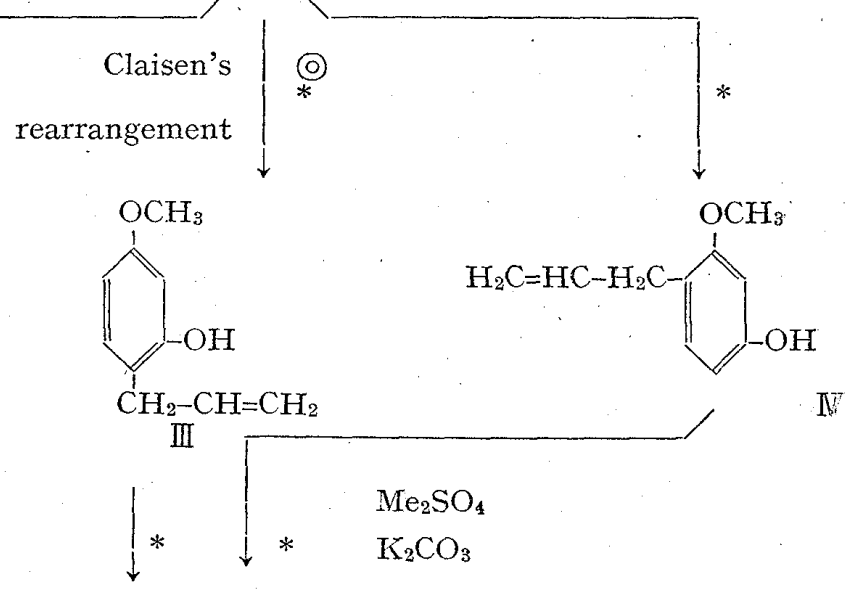

VI

osmorhizole

iso-osmorhizole

(=nothosmyrnole)

证

Chart 1. The Synthesis of Osmorhizole and Isoosmorhizole 
thylendioxy-1-allylbenzene) - $\rightarrow$ nothoapiole の系列が考兄られ生合成経路むこのように類推されるので，dillapiole は safrole, myristicin, apiole 执よび nothoapiole と成分分類学では相同とみられ，また天然フェニルプロ ペン系成分に通例 ${ }^{17 の ~} \mathrm{C}_{3}$ 側銷に詨し 1 洒ではパラ位に，2 価では 3,4 位に, 3 便では $3,4,5$ 位に, それぞれフェ ノール性酸素結合をもつ系列に属するからである。

フェニルプロペン系精油成分以外でもベンゼン核に $\mathrm{C}_{3}$ の側鎖をもつものでは，一般にシキミ酸経路を経て合成 されるのであるが，レゾルシン型の化合物はまれな化合物に属し，フラボノイドでも morin $\left(3,5,7,2^{\prime}, 4^{\prime},-\right.$ pentamethoxyflavone) など少数例 ${ }^{18)}$ に過ぎず，植物成分としての分布も狭い範囲の植物群に限定されている.ゆえに 2,4-dimethoxy-1-allylbenzene 拉よび nothosmyrnole も精油成分としては異例でありセり科です狭い範国の分 布が考えられる：このことは，同様にフェニルプロペン類を多く含むウマノスズクサ科 Aristolochiaceae のたン アオイ類 (Asarmm Asiasarum および Heterotropa 属) の各種精油にもこれら成分が見出せないことから新然 と思われる。また 2,4-dimethoxy-1-allylbenzene お占び nothosmyrnole がカサモチに含まれるといら報告は，

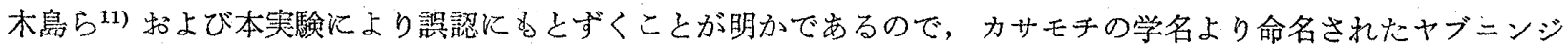
ンの成分 nothosmyrnole 改名を提案したい。すなわち 2,4-dimethoxy-1-allylbenzene に刘し osmorhizole と新たに命名し，これまで nothosmyrnole と㭔んでさた対応 propenyl 体を isoosmorhizole と改称したい。こ のようにするとフェニルプロペン系精油成分では， propenyl 体が一般に iso-を付けて呼ばれるので一層好都合で ある.

なた osmorhizole および isoosmorhizole の合成を高橋10) の方法により行なった所，Chart 1 に示す知見を得 たので就せて報告する。

高橋 ${ }^{10)}$ は 2,4-dimethóxy-1-allylbenzene (osmorhizole) を合成するに当って Claisen 転位がオルト位拉よびパ ラ位に起るとして*印の経路を考㝋ており，乙たがってメチル化により2,4-dimethoxy-1-allylbenzene のみを与 えると報告しているが，この方法で合成したものは GC で 2 種の化合物の混合を示すので，アルミナルよるカラ ムクロマトグラフィーにより分離したところ，それぞれ 2,4-dimethoxy-1-allylbenzene および 2,6-dimethoxy1-allylbenzene であることが判明した。したがって Claisen 転位はいずれるオルト位に行なわれ@印の二小向が あることを示している。

\section{実験 の 部}

精油の製造 それぞれの材料老粉矿し水蒸気苲留により製造した。用いた材料はつぎのよらである。

唐蓠本一一清水市荷居屋薬局より入手した香港経由の翰入品で, 外観は著るしく結節状センキュウに類似する

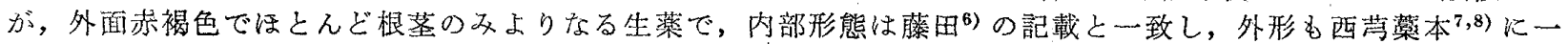
致するので原植物をLigusticum sinense OLrv.と考定したもの. 収油率 $0.2 \%$.

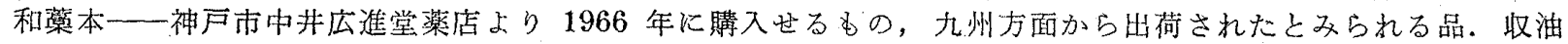
率 $0.7 \%$.

カサモチ Nothosmyrnium japonicum M MQ.一一津村研究所薬草園にて栽植されていた開花株（採集時期 10 月）

と, その株の一部を静岡薬大薬草園にて㳦培增産したもの（採取時季 5 月）.

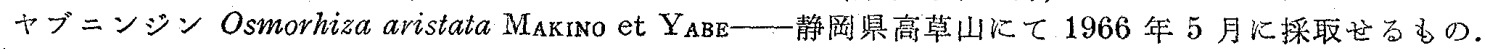

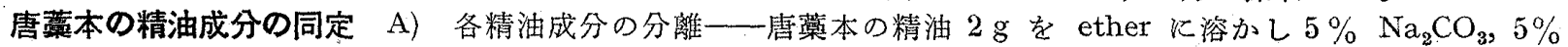
$\mathrm{NaOH}$ 拉上び $10 \% \mathrm{HCl}$ の aqueous sol, Kて順次抽出した残りの液を水洗し; 脱水 $\left(\mathrm{Na}_{2} \mathrm{SO}_{4}\right)$ した後, $\mathrm{SiO}_{2}$ (Mallincrodt) カラムに導き, ベンゼンにて展開し順次フラクションを得る. 混合物よりなるフラクションはTLC により再び分離し，TLCにより检討して同一スポットを与克るものを合併して Fr. 1-10を得た。

B) 3-Butylphthalide の証明—Fr. 8 は GC (条件は Fig. 1 および 2 と同じ) に括ける相対保持時間( $\left(\mathrm{r} t_{\mathrm{R}}\right.$, methyleugenol を基準とする): $3.08\left(10 \%\right.$ SE-30), 6.40 (20\% DEGS) 飞て 3-butylphthalide の $\mathrm{r} t_{\mathrm{R}}$ と一致。 Anal. Calcd. $\mathrm{C}_{12} \mathrm{H}_{14} \mathrm{O}_{2} ; \mathrm{C}, 75.74, \mathrm{H}, 7.42$. Found: $\mathrm{C}, 75.41, \mathrm{H}, 7.47$.

$\mathrm{UV} \lambda_{\max }^{\mathrm{EtOH}} \operatorname{m} \mu(\log \varepsilon): 228(4.05), 278(3.31), 282(3.30) . \quad \mathrm{IR} \mathrm{cm}^{-1}$ (liq. film) : 2920, 2835, $1750(-\mathrm{C}=\mathrm{O}), 1600$ (benzene) $, 1460,1340,1277,1200,1060$ (-CH-O-) $980,915,745,695$. IR, UV スペクトルは合成した標品の 3-butylphthalide のスペクトルと一致した.

C) Cnidilide の証明—Fr. 9 は, GCにて $\mathrm{rt}$ R: $3.70(10 \% \mathrm{SE}-30), 6.28(20 \% \mathrm{DEGS})$ にでキュウLigusticum officinale より分離した cnidilide $の \mathrm{r} t_{\mathrm{R}}$ と一致.

17）柴田承二，山崎幹夫，“植物成分の生合成,”東京化学同人，1965, p. 154.

18) T.A. Geissman, "The Chemistry of Flavonoid Compounds," Pergamon Press, 1962, p. 423. 
IR $\mathrm{cm}^{-1}$ (liq. film):2925, 2830, $1750(-\mathrm{C}=\mathrm{O}), 1470,1350,1280,1175,1125,1020,980,965,870$ で, cnidilide:の標品のIRスペクトルと一致.

D) 成分 X一Fr. 10 は，GCにて rtR: 4.38 (10\% SE-30), 8.51 (20\% DEGS) で, トウキ Ligusticum acutilobum の成分 ligustilide の $\mathrm{r} t_{\mathrm{R}}$ と一致与るが, TLC (plate: $\mathrm{SiO}_{2}$, solvent: ベンゼン) にて Rf 0.3 附近に紫外線 下暗色, $\mathrm{H}_{2} \mathrm{SO}_{4}$ にて紫色の spotを与光る. Ligustilide は Rf 0.6 附近に紫外線下白色, $\mathrm{H}_{2} \mathrm{SO}_{4}$ にて淡褐色の spotを与え異なる。

IR $\mathrm{cm}^{-1}$ (Iiq. film) : $3500(\mathrm{OH}), 2950(\mathrm{CH}), 2860,1750(-\mathrm{C}=\mathrm{O}), 1450,1330,1210,1180,1030,930,775$.

E) 微量成分一 $\mathrm{r} t_{\mathrm{R}}$ の比較で推定した。

和毫本およびヤブニンジンの精油成分の同定、和橖本とヤブニシジンの精油のガスクロマトグラムはすべて

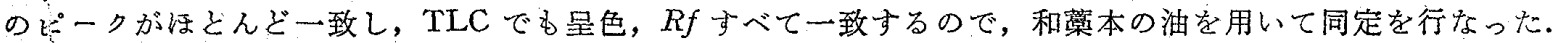

A) 各精油成分の分離——精油 $7 \mathrm{~g}$ 常唐藥本精油と同様に処理し中性部を得た後, $\mathrm{Al}_{2} \mathrm{O}_{3}$ (和光, クロマト用) カタム $(100 \mathrm{~g})$ Kて pet. ether を展開溶媒としてクロマトグラフィーを行ならと, 最初に anethole 否気をるつ 流下物を得 (Fr. 1) (30 ml ずつで, No. 13-17)，続いて TLCにて 3 個のスポットを与える部分 (No. 18一-46)， 最後にスポット 1 個の流下部 (Fr. 3) (No.47-77) を与支る. No. 18一46の部分は $50 \mathrm{~g}$ の $\mathrm{Al}_{2} \mathrm{O}_{3}$ に上り同様の 方法で再びカラムクロマトを行ない，Fr. 1 物よび Fr. 3 と異る大ポットを与光る部分を集める (Fr.2).

B) trans-Anethole の同定—Fr. 1 は, IR cm ${ }^{-1}$ (liq.film): 1600 (arom), 1430, 1230, 1170, 1030, 960, 830, 785 で, 標品の trans-anethole と一致.

C) Osmorhizole (2,4-Dimethoxy-1-allylbenzene) の同定—-Fr. 2 は, IR cm ${ }^{-1}$ (liq. film): 1590 (arom) 1450 , 1430,1280,1250,1190,1150,1030,910,820 にて, 合成せる 2,4-dimethoxy-1-allylbenzene の IR スペクト ルと一致. UV $\lambda_{\max }^{\mathrm{EtOH}} \mathrm{m} \mu(\log \varepsilon): 268(4.04)$.

D) Isoosmorhizole (Nothosmyrnole, 2,4-Dimethoxy-1-propenylbenzene) の同定——Fr. 3 は, UV $\lambda_{\max }^{\mathrm{E}+\mathrm{H}} \mathrm{m} \mu$ $(\log \varepsilon)$ : 259 (4.17), 301 (3.67). IR cm-1 (liq.film): 1600(arom). 1450, 1280, 1195, 1157, 1120, $1035,965,825$. 以上の值は合成した 2,4-dimethoxy-1-propenylbenzene の IR スペクトルの值と同じ.

E) 微量成分一 $\mathrm{r} t_{\mathrm{R}}$ の值より推定した。

カサモチの精油成分の同定 A) 精油成分の分離一一カサモチの精油は，花期に採取した地下部，春期に採取し た地下部执よび春期採取した地上部のいずれも精油相に顕著な差をTLC 新よび GCにて認めなかったので，春 期に採取した地上部および地下部, 生品で䄪 $300 \mathrm{~g}$ を水蒸気蒸留し得た精油 $0.5 \mathrm{ml}$ を, 分離用 TLC (plate:SiO solvent: hexane-ベンゼン $(4: 1))$ にて分離し，紫外線下にて青色螢光部，灰色部拉よび黑色部に分け，それぞれ ether にて抽出した.

B) Dillapiole の同定一一青色罃光を与光る部分を抽出し，無色液体を得方。bp $122-123^{\circ}(2 \mathrm{mmHg}) \mathrm{GC}$ の $\mathrm{r} t_{\mathrm{R}}: 2.75(10 \% \mathrm{SE}-30), 3.39(20 \% \mathrm{DEGS})$ にてマルバトゥキLigusticum scoticum L INN. 溜 ${ }^{19)}$ より得た標品の dillapiole $\odot r t_{\mathrm{R}} \zeta-$ 致.

UV $\lambda_{\max }^{\mathrm{EtoH}} \mathrm{m} \mu(\log . \varepsilon): 288(3.34)$.

IR cm-1: (liq. film): 1620 (C=C), 1490, 1470,1420,1380,1280, 1200;1080, 1050 (ether), 1000, 915 (vinyl), 835. 標品の IR スペクトルと一致. TLC \& $R f$, 色調共に一致.

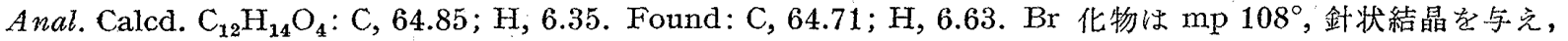
文献の monobrom-dillapiole-dibromide と同一の值を示し，標品の dillapiole上り作った Br 化物と混融する に融点降下せず，IR cm $\mathrm{cm}^{-1}(\mathrm{KBr}): 1600$ (arom), 1470, 1435, 1400,1380, 1250, 1195, 1155, 1105, 1070, 1055, $995,975,940,920,840,765$. にて標品の $\mathrm{Br}$ 化物と一致.

C) Nothoapiole (2,3,6-Trimethoxy-4,5-methylendioxy-1-allylbenzene)の同定一一紫外線下灰色を呈古る部分

を分離用 TLCにてふたたび精製し，紫外線下にて青色螢光部を完全に除くと，油状物質少量を得る。IR $\mathrm{cm}^{-1}$ (liq. film): 1600 (arom.), 1450, 1410, 1240,1190, 1080, 1050 (ether), 990, 910, (vinyl). NMR 特よびMS スぷ クトルはFig. 3 扰よび 4 飞示した. UV $\lambda_{\max }^{\mathrm{EtOH}} \mathrm{m} \mu(\log \varepsilon): 283(4.05), \lambda_{\max }^{\mathrm{EtOH}} \mathrm{m} \mu(\log \varepsilon): 261.5$ (3.71).

少量のため元素分析は行なわなかった。

Osmorhizole と 2,6-Dimethoxy-1-allylbenzene の分離および同定高橋10)の方法により resorcinol methyl allyletherをClaisen 転位させて得た成績体を常法によりメチル化し，得た溜状物質の bp $157-164^{\circ}(55 \mathrm{~mm} \mathrm{Hg})$ の留分 $5 \mathrm{~g}$ を, $100 \mathrm{~g} の \mathrm{Al}_{2} \mathrm{O}_{3}$ (和光，クロマト用)のカラムに導き pet. ether にて展開し $30 \mathrm{ml}$ づい分割すれ ば，No. 30-40 (A) 扰よび No. 55-60 (B) に TLCにて異なるスポットを 1 個のみ与光つラクションを得る. No. 41-54 は两者の混合物である. (A) は TLC (plate:SiO ${ }_{2}$, solvent: hexane-ベンゼン (1:1))にてRf $0.8, \mathrm{H}_{2} \mathrm{SO}_{4}$ にて赤紫色の spotを与光る. IR cm-1 (liq. film): 1590 (arom), 1460, 1250, 1200, 1125 (ether), 900 (vinyl), 775 (1,2,3-substituted benzene), 730 (ditto).

Anal.Calcd. $\mathrm{C}_{11} \mathrm{H}_{14} \mathrm{O}_{2}$ : C, 74.13; H, 7.92. Found: C, 74.22; H, 7.90.

以上の結果加 2,6-dimethoxy-1-allylbenzene と同定.

(B) は TLC にて Rf 0.7. $\mathrm{H}_{2} \mathrm{SO}_{4}$ にて青紫色となる. IR $\mathrm{cm}^{-1}$ (liq. film) : 1590 (arom.), 1450, 1430, 1280,

19）邚米達夫, 寺本，仁，薬誌，59,313(1939). 
$1250,1190,1150,1030$ (ether), 910 (vinyl), 830 (1,2,4-substituted benzene), 785 .

Anal. Calcd. $\mathrm{C}_{11} \mathrm{H}_{14} \mathrm{O}_{2}: \mathrm{C}, 74.13 ; \mathrm{H}, 7.92$. Found: $\mathrm{C}, 74.23 ; \mathrm{H}, 7.96$.

以上の結果から 2,4-dimethoxy-1-allylbenzene (osmorhizole) と同定.

謝辞元素分析を担当された本学分析センタ一成田九州男, 加藤智枝, 河村久代の諸氏，NMR スペクトル の測定をされた片山誠二氏，UVスペクトルの湘定をされた豊田孝子氏に梁謝します。

また実験汇協力された森田俊夫，传々木久子の両氏に梁謝します。

またカサモチの生品を睗り，かつ当献調查に協力を載いた津村研究所の佐々木一郎氏执よび秋山喜彦氏に深謝 します。 